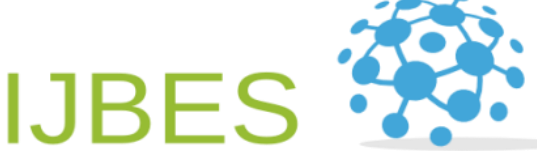 \\ Business Ecosystem \& Strategy \\ IJBES VOL 2 NO 3 ISSN: 2687-2293 \\ Available online at www.bussecon.com \\ Journal homepage: https://www.bussecon.com/ojs/index.php/ijbes
}

\section{Exploring the Development of Medical Tourism Industry in Southeast Asia Region}

\author{
(iD Suseela Devi Chandran ${ }^{(a)}$ (iD Fadilah Puteh ${ }^{(b)}$ (i) Nur Alia Azmi ${ }^{(c)}$ (i) Norazah Mohd Suki(d)* \\ ${ }^{(a, b, c)}$ Faculty of Administrative Science \& Policy Studies, Universiti Teknologi MARA, 40450 Shah Alam, Selangor, Malaysia \\ ${ }^{(b)}$ Othman Yeop Abdullah Graduate School of Business, Universiti Utara Malaysia, 06010, Kedah, Malaysia
}

\section{ART ICLE INFO}

Article history:

Received 09 November 2020

Received in rev. form 29 Nov 2020

Accepted 10 December 2020

\section{Keywords:}

Healthcare Services, Medical

Tourism, Medical Tourists, Southeast

Asia region

JEL Classification

M30, M31, M39

\begin{abstract}
A B S T R A C T
Medical tourism is a global phenomenon in many parts of the world. It features an activity where individuals travel from home country to the host country to seek or receive medical healthcare. Being the third largest sector, medical tourism has a significant contribution towards economic development in the Southeast Asia (SEA) region. However, the literature review depicts a scarcity of research on niche areas among the top player in this region. This study aims to explore the development of the medical tourism industry in the SEA region. An in-depth interview with stakeholders and private hospitals were conducted and analyzed using thematic analysis coupled with document analysis from various secondary data. Four SEA regions were chosen namely Malaysia, Indonesia, Thailand, and Singapore which offer specific niche markets to promote the medical tourism industry. Interestingly, these countries are complementing and not competing with each other in the same industry. This study is vital in enriching the literature in the field of medical tourism in showcasing the niche market of medical tourism in the SEA region. This study also contributes greatly to comparative analysis between these countries in the medical tourism sector.
\end{abstract}

(C) 2020 by the authors. Licensee Bussecon International, Istanbul, Turkey. This article is an open access article distributed under the terms and conditions of the Creative Commons Attribution 4.0 International license (CC BY) (http://creativecommons.org/licenses/by/4.0/).

\section{Introduction}

Medical tourism contributes significantly to the economic growth in the Southeast Asia (SEA) region. It implies that both tourism and medical treatment take place at the same time when people travel from home country to host country to receive medical healthcare and services (Cohen, 2008; Herrick, 2007; Reddy \& York, 2010). The region's real GDP is growing at 5.1\% in 2018, in comparison with Latin America with the GDP growth around 2\% (Emerhub, 2018). The region is focusing on three global trends that are worth capitalizing to increase productivity and billions in economic value by 2030 through: (1) capturing a greater share of global trade flows, (2) riding the urbanization wave, and (3) deploying disruptive technologies (Emerhub, 2018). The industry development is the result of the broad globalization of healthcare services (Herrick, 2007). It is featured by lessened regulatory boundaries between the countries, and ease of cross border movement for medical treatment. Besides, medical tourists travel from higher income developed countries to low-cost developing countries for the purpose of seeking medical treatment and co-joined with potential visitation for vacation. The movement of medical tourism is rapidly gaining momentum among tourists; and they are becoming more aware of the pull factors offered in the SEA region.

Sultana et al. (2014) noted several key medical tourism destinations such as Costa Rica, Hong Kong, Hungary, India, Israel, Jordan, Lithuania, Malaysia, Indonesia, Philippines, Singapore, Thailand, and United Arab Emirates. For the past few years, several countries in the SEA region such as Singapore, Thailand, Malaysia and Indonesia have also attracted medical patients not only to seek treatment, but who also contribute to the economic growth of the region particularly in the tourism sector (Johnston et al., 2015; Lee \& Fernando, 2015).

* Corresponding author. ORCID ID: 0000-0002-8422-2449 Tel.: +603-55435884; +604-9287143; fax: +604-9287160. (C) 2020 by the authors. Hosting by Bussecon International Academy. Peer review under responsibility of Bussecon International Academy. http://dx.doi.org/10.36096/ijbes.v2i3.193 
This study aims to explore the development of medical tourism industry in SEA region. The ensuing section discuss the niche area of medical tourism among these key nations in the SEA region. This is followed by a discussion whether medical tourism in SEA region would complementing and competing each other.

\section{Literature Review}

Medical tourists seek their medical treatment in the SEA region mainly due to the affordable price of the treatment (Jaapar et al., 2017). Tourists prefer to visit Malaysia, Singapore, Thailand and Indonesia to seek medical treatment due to the costs of medical treatment are cheaper compared to those in developed nations (Mun et al., 2014). Moreover, the increased affordability of the currencies from developed countries compared to SEA region currencies is another reason medical tourist are attracted to obtain their treatment in SEA (Borneo Post Online, 2015). For example, a heart bypass in the United States can cost up to US $\$ 123,000$ whereas in Malaysia the same operation will only cost US\$12,100. This alone saves the patient of $80 \%$ for medical treatment. Furthermore, due to better and different ranges of treatments and cost spectrums, the SEA region has attracted high volume of medical tourists. Another factor that contributes to the increase is these four countries have remarkable tourism attractions sites. Medical tourists do travel to obtain medical treatment as well as to go for tourism activities. This proves that $80 \%$ of medical tourists would travel to SEA countries for medical treatment and for vacation (Khan \& Alam, 2014). They also mentioned that the tropical climate of the SEA region often speeds up the recovery period. Among the popular sight-seeing attractions in the SEA region are Petronas Twin Tower and Langkawi (Malaysia), Lake Toba and Jakarta (Indonesia), Phuket (Thailand) and Universal Studios Singapore (Singapore). Although countries in the SEA region generally have some similarity in terms of factors, nations in the region have undergone different development to be successful in the medical tourism industry in their own specialties. Hence, the next subsection, discusses the niche areas of medical tourism in selected countries in SEA region namely Singapore, Thailand and Malaysia.

\section{Medical Tourism in Singapore}

Singapore has high-innovation and current medicinal equipment that are equal with the western countries. In terms of medical tourism industry, Singapore has achieved a rapid economic growth in the global market economy (Singapore Tourism Board, 2015). Singapore was ranked 11th out of 141 countries, in the International Travel and Tourism Competitiveness Index. The top five countries that visited Singapore in 2016 for medical treatment were Indonesia, Malaysia, China, United States and Philippines (The Business Journal, 2018). The medical tourism niche of Singapore is characterized by the advanced medical treatment (Lim, 2015). An Executive officer from Prince Court Medical Centre, Kuala Lumpur acknowledged that Singapore has always been a big player in SEA medical tourism and that it has a reputation for modern facilities and advanced technology. Among the advanced medical surgeries that are most sought after in Singapore are advanced cancer treatments, advanced major abdominal surgery, advanced bypass surgery and minimally invasive surgeries and robotic operations. There are three independent statutory boards that drive Singapore medical tourism industry which are the Singapore Economic Development Board (EDB); the International Enterprise Singapore (IES); and the Singapore Tourism Board (STB) (Ganguli \& Ebrahim, 2017). Together they monitor the strategy implementation regarding medical tourism by the Ministry of Trade \& Industry (MTI), and the Ministry of Health (MoH). The 2003 "Singapore Medicine" initiative was created as a backbone for strategic government-industry partnership aimed to boost and sustain Singapore's position as a global medical hub. The initiative targeted medical tourists, clinical and biomedical research and development activities, modern medical technologies, international healthcare-related conventions and exhibitions. Besides that, Singapore has established the Public-Private Partnerships (PPPs) in medical tourism combined with the public-private framework in healthcare provision and financing. This initiative led to the sustainability and formation of a solid foundation to carry out the medical tourism related activities. Ganguli and Ebrahim (2019) asserted that Singapore has competitively placed themselves in the global market through leveraging on these advanced medical treatments.

\section{Medical Tourism in Thailand}

One of Thailand's efforts to fix its financial status is to promote health tourism through global marketing, which means international patients come to Thailand for medical treatment (Lee \& Park, 2013). Thailand's efforts were fully based on individual private hospitals and low-cost procedures with a strong purport to attract foreign patients to come to Thailand. Growing at a yearly rate of $16 \%$, Thailand is among the top medical tourism destinations in the SEA region which tourists are mainly from Japan, China, Taiwan, United States and South Korea (Eden, 2012; Rerkrujipimol \& Assenov, 2011). Thailand's niche area in medical tourism is the transgender procedures, specifically in sex reassignment procedures. Even before they started to promote the medical tourism industry, Thailand was already known to the world to be an expert on this specific treatment and is the only country in the world that has conducted this treatment extensively. Furthermore, Thailand boasts several international experts that possess strong academic and have medical training with more than 10 years of experience in performing transgender surgery. A doctor from the Imperial Dental Specialist Centre, Kuala Lumpur, Malaysia also opined that Thailand has a great reputation for transgender procedure. Besides, medical tourism development of Thailand is credited to the active role of the Thai government whereby the Ministry of Public Health (MPH) Thailand is responsible in ensuring the safety of the visitors, introduce adequate medical visas for longer staying, provide malpractice insurance and maintain sufficient supply of skilled medical personnel. Thai government acts as key actor in facilitating as well as developing medical policies in the industry. The operations of healthcare facilities and licensing of 
medical doctors and nursing professionals are closely monitored and are subjected to Medical Facility and Medical license laws and policies. The Thai government also revises various policies that covers both medical service providers and travel agents from time to time. This shall enable them to fully utilize the medical resources available. As at 2007, about 17,792 private healthcare service providers, including over 330 hospitals, offered medical related services. In 2010, 197 private healthcare providers were recommended as medical tourism service suppliers, whereas the well-known Bumrungrad International Hospital still represents Thailand as the world's leading medical tourism service provider (Maierbrugger, 2015).

\section{Medical Tourism in Malaysia}

Malaysia's medical tourism industry contribution to economic development has been made possible over the last three decades. With respect to medical tourism in Malaysia, the industry has reached the second highest non-public investment provider at RM24.5 billion and the third major GNI provider at RM67.1 billion (Connor, 2016). Malaysia has been striving to provide Syariah medical practices to worldwide Muslim medical tourists. Although this practice is relatively new, it is evolving rapidly and has resulted in Malaysia to become Muslim patient's favorite destination, particularly those from Middle East nations such as Jordan and Libya (Ormond et al., 2014). This bold move is well accepted by Muslim patients particularly from Islamic countries around the globe. The concept of Syariah compliance in medical tourism by the Malaysian government also caters to the need for medical services and treatment among Muslim patients such as protecting their aurah or aurat from their Ajnabi (people who are restrained to look and touch the skin and other parts of the patient's body except their siblings and close relatives). Moreover, Malaysia responded actively towards a growing demand for halal medical tourism in the SEA region, especially from Indonesia. Halal medical tourism refers to medical tourism which follows to the guidelines under the Islamic law known as Syariah Law (Abdullah et al., 2014). As such, healthcare providers provide halal medications solution such as porcine-free gelatin capsules for medications and non-porcine insulin. Apart from that, healthcare providers also pay serious attention and consideration by offering Muslim-friendly services such as halal food, Qiblat directions, prayer facilities, on demand doctors and nurses from the same gender of the patients and if required, offers funeral services according to Islamic requirements (Abdullah et al., 2014). Being part of Organization of Islamic Cooperation (OIC) community, Malaysia has gained its popularity as top medical tourism destination among Muslim countries with bundles of unique halal medical tourism by-products.

Notably, the medical tourism industry in Malaysia is actively steered by both government and private sectors. These include private healthcare providers particularly in the state of Penang, Melaka, Selangor and Kuala Lumpur together with respective state governments; private hospital associations; Ministry of Health (MOH); Tourism Malaysia, and Malaysia Healthcare Travel Council (MHTC). Other federal agencies are also involved in medical tourism development including Halal Development Centre (HDC) as well as Ministry of Tourism and Culture (MOTAC). Moreover, the Malaysian government provides a comprehensive set of laws and regulations for medical tourism hospitals, ministries and agencies that govern best practices of medical tourism in Malaysia (Leng et al., 2007). Besides that, the government has emphasized on the policy, in which all medicines and pharmaceutical products must obtain certification and the halal logo (Leng et al., 2007). The approval for the halal certification and halal logo utilization is placed under the strict supervision of Islamic Affairs Department, known as the Jabatan Kemajuan Islam Malaysia (JAKIM) or with cooperation from other relevant statutory bodies. All the medicine and the pharmaceutical products that utilize the halal logo must meet the requirements of Islamic laws before the halal certification is granted. The certification ensures the total quality, health and sanitary requirements for the slaughtering, preparation, processing and other related operations are in accordance with Islamic principles (Hallalan Toyyiban). Medical tourists are attracted to culture attractions. Malaysia consist of several groups that form a colorful cultural mix. Each ethnic group has its own traditions and one can experience several celebrations and festivals every year. In addition, the festivals in Malaysia such as Thaipusam, Gawai and Hari Raya have attracted medical tourists to travel and celebrate the festivals as well.

\section{Medical Tourism in Indonesia}

Indonesia, most famous for its spa treatments and holiday destinations, is responding actively to the development of medical tourism though signing of MoU between the tourism ministry and the health ministry of Indonesia (International Medical Travel Journal, 2013; Leng et al., 2007). Indonesia attracts its foreign patients through a number of factors namely the affordable cost of treatments and beautiful beaches which has attracted international tourists to do cosmetic surgery at the hospital including blepharoplasty, liposuction and breast enhancement (Johnston et al., 2015; Retalk Asia, 2017). Indonesia medical tourism industry is growing highly and maintains a great reputation among tourists in terms of excellence services plus one of the best medical cares that a medical tourist can receive (Thomas, 2019). The other most mentioned medical specialization in Indonesia would be dentistry. The costeffective medical treatments, availability of advanced equipment and highly trained healthcare staff have made Indonesia famous among global tourists (Retalk Asia, 2017). The development of medical tourism in Indonesia has a big potential considering the location and Indonesia's advantages for medical tourism. The partnership between the two ministries involves policy and program coordination and harmonization, medical tourism improvement, development, education for the locals who live around medical tourist destinations, information and data exchange (The Jakarta Post, 2017). Although spas and traditional health are not entirely supported by scientific principles in Indonesia, the unique and traditional health treatments are remained preserved and supported 
scientifically in order to become sustainable and able to compete globally. The Indonesian government is confidents that the medical tourism industry has great potential to be successful like its neighbouring country, Malaysia.

\section{Medical Tourism in SEA Region: Between Complementing and Competing}

Most of the SEA region medical tourism was established and developed systematically since the 1997 Asian Financial Crisis. These major players have diversified their income sources through promoting affordable and high-quality medical care to attract foreign patients. Although each of the nations is focusing on their niche areas, interestingly they are complementing each other in enhancing the medical tourism sector. This is due to the broad factors that influence medical tourists to travel to the countries for healthcare reasons. One of the factors is access to treatments are unavailable in their native countries. Notably, the Head of International Marketing from Sunway Medical Centre, Kuala Lumpur, Malaysia highlighted that there are treatments that are not available through the local healthcare structures. For example, Singapore is not able to carry out transgender surgery due to limited health experts in their country; hence, patients need to travel to Thailand to obtain the treatment. Therefore, SEA nations are complementing each other's medical specialties to assist patients traversing the region to seek for medical care they cannot find or afford at home country. Another reason SEA nation is perceived as complementing with each other is due to patients from within the region that are the driving factor for the industry. Contrary to popular belief, rapid development of medical tourism in this region is contributed to large number of medical tourists come from within the SEA region itself. The Senior Executive, Public Relations and Brand Communication, Malaysia Healthcare Travel Council (MHTC), Kuala Lumpur, Malaysia opined that Indonesia and Thailand have been identified as Malaysia's focus markets based on the volume of healthcare travelers, as well as growth potential of Malaysia's medical tourism. There are several conventional factors why SEAs patients are travelling for healthcare motives. This includes cost, shorter waiting times for procedures, and affordable travel expenses. For example, medical tourists from Indonesia are travelling to Malaysia for health care screenings. This is because they have limited access to quality medication or lab analyses or access to trusted doctors in their country. Singapore, on the other hand, has limited health experts that treat transgender procedure; therefore, Singaporeans travel to Thailand to obtain the treatment. In addition, what is emerging in the SEA region is south-to-south travel. Patients from one developing country travel to another developing country to obtain medical treatment. Each of the nations is aware of the specialties that each of them possesses within the SEA region medical tourism industry; hence, they are complementing with each other. This is perhaps one of the significant reasons that dictate the rapid development of medical tourism industry among these four key nation players.

\section{Conclusion}

This study explores the development of medical tourism industry in the SEA region. The study reveals that medical tourism in the SEA region has prospered in recent years, especially in Malaysia, Indonesia, Thailand, and Singapore. The constructive economic development experienced in the region has enabled more individuals, particularly foreign patients in developed countries to seek for medical treatment and vacation. The development of medical tourism industry in these four countries are created fundamentally for monetary reasons. This new industry contributes billions of dollars a year in terms of income, and it is worth to focus on its tremendous development. In the SEA region, these key nations are making a mark in the medical tourism industry by leveraging each of their own specialized medical area. This study offers clear understanding via comparative analysis between four key major players in the SEA region. It can be concluded that despite rapid development in their country, these key players of medical tourism in SEA nations are complementing each other in the industry. While each of the nations is focusing on their niche area, there are other markets that can be further explored. The ability of the SEA region to further develop and sustain as top medical tourism destinations depending on whether they could cope, deliver and exceed medical tourists' expectations. This is pivotal for the sustainability of future medical tourism development in the SEA region. Future research is recommended to execute quantitative research design in order to examine factors influencing medical tourists' behavior in the SEA region.

\section{Acknowledgements}

The authors gratefully acknowledge the help of UiTM in providing the FRGS grant. This work was supported in part by Research Management Centre (RMC) Universiti Teknologi MARA (UiTM) Shah Alam, Malaysia under the FRGS Grant 600IRMI/FRGS/5/3(33)/2016.

\section{References}

Abdullah, S., Manaf, N. H. A., \& Omar, A. (2014). Medical tourism as emergent industry: Riding on the Halal wave, $150-155$.

Borneo Post Online. (2015). Malaysia well positioned to grow its medical tourism, devices sectors. Kuching. Retrieved from http://www.theborneopost.com/2015/01/27/malaysia-well-positioned-to-grow-its-medical-tourism-devices-sectors/

Cohen, E. (2008). Medical tourism in Thailand. ResearchGate.

Connor, L. (2016). Region's medical tourism boom fuelled by Southeast Asians. Southeast Asia Globe. Retrieved from http://seaglobe.com/southeast-asians-drive-medical-tourism/

Eden, C. (2012). The Rise of Medical Tourim in Bangkok. Retrieved from http://www.bbc.com/travel/story/20120828-the-rise-ofmedical-tourism-in-bangkok 
Emerhub. (2018). Southeast Asia Economic Outlook 2018. Retrieved from https://emerhub.com/insights/southeast-asia-economicoutlook-2018/

Ganguli, S., \& Ebrahim, A. H. (2017). A qualitative analysis of Singapore's medical tourism competitiveness. Tourism Management Perspectives, 21, 74-84.

Herrick, D. (2007). Medical tourism: Global competition in health care. National Center for Policy Analysis (Vol. 75251). Retrieved from http://w.medretreat.com/templates/UserFiles/Documents/Medical Tourism - NCPA Report.pdf

Jaapar, M., Musa, G., Moghavvemi, S., \& Saub, R. (2017). Dental tourism: Examining tourist profiles , motivation and satisfaction. Tourism Management, 61, 538-552.

Johnston, R., Crooks, V. A., \& Ormond, M. (2015). Policy implications of medical tourism development in destination countries: Revisiting and revising an existing framework by examining the case of Jamaica. Globalization and Health, 1-13.

Khan, S., \& Alam, M. S. (2014). SAU: A potential destination for medical tourism. Journal of Taibah University Medical Sciences, 9(4), 257-262.

Lee, H. K., \& Fernando, Y. (2015). The antecedents and outcomes of the medical tourism supply chain. Tourism Management, 46, $148-157$.

Lee, J.-H., \& Park, N. R. (2013). M.I.C.E and medical tourism in Singapore. SSRN, 3(49). http://doi.org/10.2139/ssrn.2360985

Leng, C. H., Wade, G., \& Teo, S. (2007). Medical tourism in Malaysia: International movement of healthcare consumers and the commodification of healthcare, Vol. 83, pp. 1-32.

Lim, L. (2015). Singapore's economic development: Retrospection and reflections. Singapore: World Scientific Publishing Company.

Maierbrugger, A. (2015). Malaysia reaches out to GCC health tourists with its 'halal treatment.' Bangkok. Retrieved from http://www.gulf-times.com/story/463364/Malaysia-reaches-out-to-GCC-health-tourists-with-i

Mun, W. K., Peramarajan, V., Arshad, T., \& Nuraina, T. (2014). Medical Tourism Destination SWOT Analysis: A Case Study, 7

Ormond, M., Mun, W. K. E, \& Khoon, C. C.. (2014). Medical tourism in Malaysia: How can we better identify and manage its advantages and disadvantages? Global Health Action, 7, 25201. http://doi.org/10.3402/gha.v7.25201

Reddy, S. G., \& York, V. K. B. (2010). Travel for treatment: Students' perspective on medical tourism. International Journal of Tourism Research, 12(5), 510-522.

Rerkrujipimol, J., \& Assenov, I. (2011). Medical Tourism in Thailand and Its Marketing Strategies.

Retalk Asia. (2017). Indonesia's medical tourism set to improve healthcare for locals and attract visitors. Retrieved from https://www.retalkasia.com/news/2017/10/05/indonesias-medical-tourism-set-improve-healthcare-locals-and-attractvisitors

Singapore Tourism Board (STB). (2015). Annual report on tourism statistics 2014. Singapore: Singapore Tourism Board. Retrieved from https://www.stb.gov.sg/

Sultana, S., Haque, A., Momen, A., \& Yasmin, F. (2014). Factors affecting the attractiveness of medical tourism destination: An empirical study on India. Review Article, 43(7), 867-876.

The Business Journal. (2018). Singapore Medical Tourism Market and Forecast to 2022. Retrieved from https://www.bizjournals.com/prnewswire/press_releases/2017/08/01/SP55688

The Jakarta Post. (2017). Tourism and health ministries to develop medical tourism in Indonesia.

Publisher's Note: Bussecon International stays neutral with regard to jurisdictional claims in published maps and institutional affiliations.

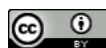

International Journal of Business Ecosystem and Strategy by Bussecon International Academy is licensed under a Creative Commons Attribution 4.0 International License. 